\title{
Article
}

\section{Shale gas and regional economic development: Enhancing local economic impact}

\author{
Whyman, Philip B \\ Available at http://clok.uclan.ac.uk/11677/ \\ Whyman, Philip B ORCID: 0000-0002-3926-1019 (2015) Shale gas and \\ regional economic development: Enhancing local economic impact. Local \\ Economy, 30 (2). pp. 215-230. ISSN 0269-0942
}

It is advisable to refer to the publisher's version if you intend to cite from the work. http://dx.doi.org/10.1177/0269094215574026

For more information about UCLan's research in this area go to http://www.uclan.ac.uk/researchgroups/ and search for < name of research Group>.

For information about Research generally at UCLan please go to http://www.uclan.ac.uk/research/

All outputs in CLoK are protected by Intellectual Property Rights law, including Copyright law. Copyright, IPR and Moral Rights for the works on this site are retained by the individual authors and/or other copyright owners. Terms and conditions for use of this material are defined in the policies page.

\section{CLoK}

Central Lancashire online Knowledge www.clok.uclan.ac.uk

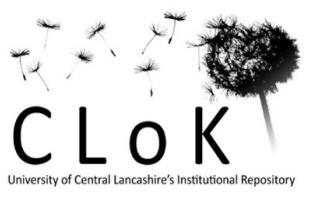




\title{
Shale gas and regional economic development:
}

\section{Enhancing local economic impact}

\author{
Philip B. Whyman
}

Corresponding Author:

Philip B. Whyman, Lancashire Instituite for Economic and Business Research, Lancashire Business School, University of Central Lancashire, Preston, PR1 2HE. E-mail: PBWhyman@uclan.ac.uk 


\section{Shale gas and local economic development: Enhancing local economic impact ${ }^{1}$}

\section{Introduction}

The expansion of the shale gas industry has been encouraged by the UK government due to its potential economic benefit. Considerations around energy security, the wealth generating capacity of an emerging energy industry to counterbalance declining North Sea production, potential reductions in energy prices for consumers and enhanced tax revenues have all generated noticeable support in government circles. Indeed, the Prime Minister has stated government strategy is 'going all out for shale' (House of Lords Economic Affairs Committee, 2014:9). Whilst negative environmental externalities are acknowledged (Wood et al., 2011:7; Green et al., 2012), it would appear that national public policymakers have concluded that, properly regulated to prevent the worst effects, the expansion of the shale gas extraction industry would produce positive net economic benefit for the UK economy. Accordingly, a programme of tax reliefs and other fiscal incentives have been announced to stimulate the development of this industry (HM Treasury, 2014:35,58). 
What is largely missing from this analysis, however, is consideration of potential local and/or regional economic impact, if the shale gas industry should expand as national policymakers and industry sources seem to assume. It is noted that the UK is a more densely populated than areas in the USA, where shale gas extraction has already proven successful. Consequently, local acceptance of the industry is considered to be essential for its long term successful development. Yet most studies have either neglected to estimate potential local impact or else have assumed that regional benefit will be fairly automatic (IOD, 2013:8; House of Lords Economic Affairs Committee, (2014a:29; 2014a:35; Ev 139). ${ }^{2}$ This omission is all the more surprising because it would seem logical for supporters of the shale gas industry to attempt to mollify local opposition through evidence-based analysis demonstrating the benefits, as well as the costs, which may derive from the expansion of the industry. Since most costs will be experienced most drastically at local level, it would seem reasonable to expect local economic benefit to exceed externalities if local communities are to acquiesce to the expansion of the industry.

This conclusion is reinforced by a recent survey of residents in Blackpool, Fylde and West Lancashire, carried out by the Britain Thinks (2013) polling agency, which has identified that support for the expansion of the shale gas industry is finely balanced, as 
concerns over environmental externalities are largely negated by anticipation for employment opportunities and benefits for the local economy. ${ }^{3}$ However, this potential level of support, or perhaps more passive acquiescence, requires the realisation of these potential economic benefits. This, in turn, emphasises the importance of a detailed consideration of the distribution of costs and benefits deriving from any expansion of shale gas exploration and extraction.

This paper, therefore, seeks to highlight the factors that local stakeholders and their representatives should consider when seeking to maximise the potential economic benefit arising out of the possible expansion of the shale gas industry in their region. The paper focuses upon the Bowland Basin, situated in Lancashire, but which is part of the more extensive Bowland-Hodder unit encompassing Cheshire, parts of Derbyshire around Edale, Cleveland and the Humber regions. This has been identified by the British Geological Survey as having the greatest potential shale gas reserves in the UK (Andrews, 2013).

\section{Background}


Shale gas is a form of natural gas contained within a commonly occurring shale rock formation. The low permeability of shale rock creates the possibility for shale gas exploration, due to the preservation of the oil and gas reserve, but it creates difficulties for the extraction process. One solution has been horizontal drilling, where the drill shaft represents an ' $L$ ' shape, in order to gain better immediate access to gas pockets. A second is to use hydraulic fracturing to enhance flow rates (Rogers, 2011:121). This process involves pumping a fluid at high pressure through the well and into the surrounding target shale rock, thereby creating fractures or fissures a few millimetres wide in the rock, for a radius of perhaps hundreds of metres away from the well bore. To prevent these fractures closing, once the pressure is released, small particles, such as sand or ceramic beads, are added to the fracturing fluid in order to infill the small fractures in the rock. These 'propanants' quite literally 'prop open' the fractures and, due to their greater permeation, facilitate the escape of the gas into the well. It is the 'fracking' process that raises particular environmental concerns (Wood et al, 2011).

Unconventional gas resources, such as shale gas, remain largely untapped and, indeed, it is only really in the USA, in recent years, where a rapid expansion in shale gas extraction has occurred. From representing only $1 \%$ of the total US gas market at the turn of the century, shale gas has grown to represent one fifth of the US market in 2009 (Stevens, 2010:vi). The IEA (2012:79-81) predicts that gas will form a rising share of 
world energy demand for the next two decades, as coal and oil experience a modest decline and, moreover, potentially two-thirds of this increase in gas supply may derive from unconventional gas sources. Consequently, it is proposed that unconventional gas has the potential to become a vital part of an increasingly important energy resource at the global level.

Potential Significance of Shale Gas in the North West

Within the UK, the British Geological Survey (BGS), in association with Department of Energy and Climate Change (DECC), have produced provisional estimates for the amount of potential shale gas which may exist within the Bowland-Hodder area. There is considerable uncertainty surrounding the precise reserves, unless or until confirmed by drilling exploration. Nevertheless, the current best estimate is provided in Table 1. The split between the upper and lower units reflects this degree of uncertainty, as the former relates to a more explored, condensed zone of laterally contiguous, organic-rich material, which is more easily mapped than an underlying area, extending thousands of feet, which is largely undrilled, but which may hold larger potential reserves. However, these deeper reserves are more difficult to access, thereby increasing both the technical difficulty and economic cost of moving beyond the upper unit estimates. The upper unit also conforms more closely to the existing North American shale gas productive zones. 
Table 1: Total Gas in Place Estimates (trillion cubic feet, tcf)

\begin{tabular}{lccc}
\hline & Low (P90) & Central (P50) & High (P10) \\
\hline Upper unit & 164 & 264 & 447 \\
Lower unit & 658 & 1065 & 1834 \\
Total & 822 & 1329 & 2281
\end{tabular}

(Source: Andrews, 2013:3)

When attempting to place a value upon the size of the potential shale gas industry, there are significant barriers, since estimates of 'gas in place' (GIP) do not, however accurate, closely reflect technically or economically recoverable gas reserves. Indeed, the latter are likely to be only a very small proportion of the GIP forecasts. There is evidence to suggest that drilling costs may be higher in the UK than the USA, albeit that higher European gas prices may offset higher cost factors (IOD, 2013:114; House of Lords Economic Affairs Committee, 2014a:40; Ev179).

One estimate assumes that the upper (more mapped) element of the Bowland field might be similar to that of Barnett Shale in Texas, in which case the economically recoverable yield would be around 4.7tcf (or 4.7bn mmbtu) (DECC, 2011; Andrews, 2013:3). ${ }^{4}$ At a current European wholesale price for gas of around US\$10 per mmbtu, 
this would value an equivalent economically recoverable shale gas reserves in the Bowland field to be in the region of $£ 28 \mathrm{bn}$ (US\$47 billion).

A more recent estimate, however, suggests that shale gas extraction could represent a larger percentage of GIP, perhaps $10 \%$ to $30 \%$ (IOD, 2013:112; House of Commons Energy and Climate Change Select Committee, 2013:Ev132-133; House of Lords Economic Affairs Committee, 2014a:33; Ev 124-5). Taking the more conservative figure, this would equate to between 26.4tcf for the upper unit central estimate and 132.9tcf if including the more uncertain lower unit forecasts. At current wholesale gas prices, this would value potential upper unit recoverable reserves at approximately $£ 157.1$ bn (US\$264bn), rising to $£ 791.1$ bn (US\$1329bn) if lower unit predictions are added. If this is accurate, then the stock of potential shale gas in the Bowland Basin could contain as much value as that previously extracted from the North Sea (House of Lords Economic Affairs Committee, 2014a:33; Ev 124-5). Furthermore, over the forecast two decade shale gas industry lifespan, this would generate between $£ 7.9$ bn and $£ 39.6$ b per annum.

Cuadilla Resources, the company licensed to explore the larger part of the Bowland shale, estimate that there is 200 tcf of GIP in their exploration field. ${ }^{5}$ This is close to the central upper unit forecast made by the British geological Survey (Andrews, 2013:3). 
Assuming $10 \%$ can be economically recovered, and at current European gas wholesale prices, this would equate to a value of approximately $£ 119 \mathrm{bn}$ (US\$200bn). Averaged over a twenty year extraction cycle, this would represent $£ 5.95$ billion per annum. To place this into context, in 2009, the 12 district Lancashire economy is worth approximately $£ 18.3 \mathrm{bn}$, representing one fifth of the economy of the North West of England. ${ }^{7}$ Therefore, if this industry prediction is accurate, shale gas could add as much as an additional $32.5 \%$ to the current size of the Lancashire economy over this two decade period.

Cuadrilla Resources have advanced a slightly higher estimated market value of $£ 136 \mathrm{bn}$, presumably by employing a more generous assumption as to the proportion of reserves can be economically recovered. ${ }^{6}$ Using Cuadrilla cost and volume estimates, alongside DECC price predictions, Deloitte (2013) estimates that Bowland shale production could generate tax revenues of $£ 580$ million per annum by 2020 and sustain peak level employment of between 6900 and 23600, depending upon assumptions made in calculations.

\section{Assessment of National Economic Impact}


The significance of the conventional North Sea oil and gas industry can be represented by its balance of payments contribution, accounting for approximately $68 \%$ of UK oil and $58 \%$ of gas demand, alongside its contribution of one quarter of all corporation tax revenues and support for approximately 440,000 jobs in the UK, whether directly, through the supply chain or induced through income multiplier effects (Oil and Gas, 2012). Shale gas development has the potential to make a contribution in each of these areas. For example, the Institute of Directors and DECC have forecast that shale gas could offset otherwise rising energy imports, as North Sea gas output falls in the future, thereby strengthening the balance of payments and providing enhanced energy security (Huppmann et al., 2011; Rogers, 2011:118; House of Lords Economic Affairs Committee, 2014a:17; 2014b:Ev24-31). It has the potential to generate significant revenue for the government (EY, 2014:31).

In terms of employment opportunities, AMEC (2013:65-6,83-4) forecasts between 2600 and 5300 total full time equivalent (FTE) jobs generated, the EY (2014) predicted 39,000 jobs throughout the supply chain at peak production, whilst the IOD (2013:130), using a different set of assumptions around the number of wells drilled at each site, forecasts a peak level of employment of 74,000 supported by the industry. A separate study, examining the potential employment effect upon the coastline of the North West, forecast a peak year impact of 15,500 jobs (AMION, 2014). In addition, an industry- 
sponsored study forecasts 6500 new jobs, based upon the assumption of 10 wells per drilling site (Regeneris, 2011:47-8). Current industry plans have extended to proposing up to 20 wells per site, however, the considerable economies of scale, witnessed in the US industry, imply that employment creation will not increase in proportion (i.e. constant coefficients) to any increase in production, but at a slower rate. Thus, if predictions assume a similar level of technical efficiency to US shale gas operations, should the Bowland field expand to 800 wells, the total workforce requirements would be likely to rise to 7858 FTEs, at an average of 9.82 per well (MSETC, 2011:29).

It is important to note that employment rates vary considerably, within the shale gas extraction industry, between the labour-intensive, but relatively short lived drilling phase, and the longer term gas extraction and maintenance phase, where far fewer people are employed. Moreover, shale gas wells tend to deplete faster than conventional gas comparators, having a life of perhaps 8-12 years rather than a more typical 30-40 years (Stevens, 2010:11). Thus, the production profile depends upon the ability to continually expand the industry, through the drilling of new wells; a fact that necessitates continuing public acceptance (Rodgers, 2013:5-6). Consequently, the IOD forecast, employment peaks approximately ten years after the start of expansion, and reaches a stable state at around 17,000 after an additional decade, whereas, for AMEC, this maintenance stage might employ as few as 200 to 1152 workers. Thus, without 
further data concerning the number of wells to be drilled, estimates of employment potential is considered to be unclear (House of Lords Economic Affairs Committee, 2014a:42; Ev191-3).

An additional potential benefit, for the UK economy, might derive from reductions in price resulting from an increased supply of gas from shale reserves. In the US, a rapid expansion in shale gas production resulted in a decline in gas prices of around $20 \%$, to the benefit of domestic customers but also enhancing the international competitiveness of energy-intensive industries (Huppmann et al., 2011:72). This might assist in the retention and/or 're-shoring' of firms in these sectors (House of Lords Economic Affairs Committee, 2014b:Ev61). Whilst predictions on the impact of shale gas on UK prices are indeterminate, it has been noted that low cost supplies of shale gas have resulted in a cost advantage over Chinese competitors exceeding the disadvantage in labour costs (House of Commons Energy and Climate Change Committee, 2013; House of Lords Economic Affairs Committee (2014a:15; 2014b:Ev11-14)

Studies of economic impact are inevitably limited in terms of the scope of their analysis, due to the difficulty inherent in incorporating dynamic effects, such that the displacement costs of other industries or externalities (i.e. environmental damage or the cost to other industries and the local community of rising costs of living and/or higher 
housing costs) tend to be left out of the equation (Weinstein and Partridge, 2011). Nevertheless, input-output modelling (Leontief, 1986) for 2005, the latest year when data is available, suggests that an increase in activity in the oil and gas sector will result in an output multiplier of 1.321 (ONS, 2005). Thus, a $£ 28 \mathrm{bn}$ increase in oil and gas production would be anticipated to result in an estimated total benefit to the nation as a whole of some $£ 37 \mathrm{bn}$, after the beneficial impact on supply chains has been taken into consideration. Alternatively, the forecast made by Cuadrilla Resources for potential economically recoverable shale gas reserves might signify a national economic impact of $£ 157 \mathrm{bn}$.

There are a number of reasons to be cautious about the precise national economic impact which may arise from the expansion of the shale gas industry, not the least of which derives from the considerable uncertainty involved in identifying the size of recoverable reserves. Moreover, access to these reserves is likely to prove more complicated in the UK than in the US, because the former is a more crowded island, with proportionately less land available for drilling without generating significant disruption externalities for established communities. Moreover, UK landowners do not own the rights to minerals and hydrocarbons beneath their land - this belongs to the Crown - and therefore there are fewer incentives for landowners to cooperate in the exploration and extraction process (White et al, 2014). 


\section{Local Economic Impact}

For the US studies, a commercially developed IMPLAN input-output model has typically been used to generate a multiplier estimate for regional economies. ${ }^{8}$ The most prominent amongst the work in this area has been Considine and his team, from Pennsylvania State University, whose estimates of output multipliers have generated a fairly consistent 1.9-1.94 range, whilst employment multipliers have been estimated to lie between 2.03 and 2.05 (Snead and Barta, 2008; Considine et al, 2009, 2010; Considine, 2010; Weinstein and Partridge, 2011). In the UK, however, the Office for National Statistics (ONS) does not produce input-output tables on a regional basis, and whilst devolved (Scottish, Welsh and, to a lesser extent, Northern Irish) governments have produced their own disaggregated models, this does not provide an adequate basis for a study seeking to estimate the more localised impact of an industry moving to a specific English region.

Estimates for the impact experienced in specific regions or localities in the UK would be expected to be smaller, as benefits leak out of local economies to benefit firms and employees located elsewhere in the UK and, indeed, abroad; presumably the latter is 
one of the reasons why national UK multiplier estimates are smaller than regional American comparators. The fact that approximately $45 \%$ of total oil and gas employment in the UK is located in Scotland, with a particular concentration in and around Aberdeen, indicates the existence of a successful cluster of energy supply companies, whereby an expansion in shale gas exploration may rely upon the skills and technical machinery derived from this region (Aberdeen City Council, 2012; Oil and Gas, 2012). Agglomeration effects may, therefore, require significant incentives or market rewards to consider significant relocation closer to the point of shale gas drilling sites.

The absence of a local or regional input-output method of calculation resulted in the industry consultancy group, Regeneris (2012), adopting a forecasting methodology utilising input-output estimates for the UK economy as a whole (1.3) and supplementing this with data derived from industry sources. Thus, Regeneris (2011:37) note that, in the initial test well phase of exploration within the Bowland region, only $15 \%$ of jobs were taken by Lancashire residents, whereas around $17 \%$ of industry expenditure could be identified as being spent upon local employees and suppliers. This gave rise to multiplier estimates of 2.1 at national level, and 1.5 locally, with peak level job creation of between 1700-2500 in Lancashire, incorporating those employed directly, subcontracted via agency or consultancy, employed by one of the shale gas supply chain, or 
induced elsewhere in the region (Regeneris, 2011:37-48; 2012). Unfortunately, this methodology suffers from two weaknesses, in that, firstly, input-output estimates should have been used from the oil and gas industry rather than the average for the UK economy as a whole, and secondly, these should have been substituted (not augmented) by data drawn from supply chain calculations and second stage multiplier effects deriving from employee expenditure (Regeneris, 2012). This double-counting overinflated multiplier estimates.

An alternative forecast for employment creation, in the Ocean Gateway (coastline) area of the North West, is based upon the twin assumptions that a significant proportion of the supply chain relocates to the area and that local residents are equipped with the necessary skills to work in the industry. On this basis, the report predicts a peak year total is some 3,500 jobs (AMION, 2014). This would represent around $23 \%$ of all jobs predicted to be created by the industry.

Local economic impact depends upon the size of the initial boost to the local economy, through direct expenditure by the emergent industry (whether through the consumption patterns of employees or expenditure through the supply chain located within the area), multiplied by indirect (subsequent supply chain expenditure) and induced (multiplier) effects. Consequently, even if the multiplier estimate is found to be in the region of 1.3 
if regional benefit mirrored national impact calculated by input-output analysis, or 1.5 as estimated by industry consultants, if the initial expenditure located within the local economy is small, the ultimate effect upon the local economy will remain relatively small even after inflated by the multiplier effect.

The evidence, obtained from industry sources, operating within the Bowland field at this early stage of exploration, would suggest that only $1.94 \%$ of supply chain value is allocated to firms based in the Lancashire area, and $4.12 \%$ in the North West as a whole, compared to just over one tenth of the total flowing to firms based overseas. The latter may be an under-estimate given that predictions, made by AMEC (2013:69) and Regeneris (2011:36), suggest that 29\% and one third of supply chain expenditure will be located overseas. Moreover, Regeneris (2011:37) found that, in the initial test well phase of exploration within the Bowland region, only $15 \%$ of jobs were taken by Lancashire residents. Consequently, it would appear that the key factors, determining the size of local economic impact, derive from the extent to which the advent of the new industry impacts upon the local labour market, through employment of local residents and enhancing human capital formation, together with the development of a local cluster of firms servicing the industry. 
This conclusion confirms similar findings from previous studies. Local companies tend to possess extensive local linkages resulting in stronger local multiplier effects than large companies doing business in many different regions and countries. Moreover, local supply-side effects are associated with different company and city-regional characteristics. Thus, indirect multiplier effects are typically stronger with companies which have been operating in a specific location for a lengthy period of time. Similarly, service sector firms tend to have a higher local impact than manufacturing companies, largely because employment costs are a more significant proportion of expenditure for the latter than the former, thereby anchoring a greater share of initial expenditure in the local economy. Furthermore, the larger the city-region, the less significant are the leakages from a given economic boost, and therefore the greater the resulting local income multiplier (Domanski and Gwosdz, 2010). Finally, the inter-relationship between firms has been found to be highly significant, in terms of delivering regional multiplier effects, as agglomeration effects, through the growth of clusters and resultant informational flow between firms, tend to spillover into skills development and local income growth (McCombie and Thirwall, 1994; McCann, 2013:169).

\section{Policy Implications}


The size of the local economic impact, arising from the expansion of the shale gas exploration and extraction industry, will largely depend upon the proportion of employees to be drawn from the local region and the relocation of a sizeable share of the supply chain within the local economy. These conclusions have implications for local and national policymakers. For example, the Lancashire Local Economic Partnership City Deal has outlined "significant opportunities" deriving from shale gas expansion in the region, with the energy sector being identified as a key component for growth, jobs and skills development. ${ }^{9}$

\section{Skills Formation}

There is some evidence, drawn from industry predictions and US studies, that the share of employment taken by local residents will expand over time, as the industry becomes more established in the region (Regeneris, 2011:41). Indeed, there are limited but encouraging signs to indicate that entry level vacancies are actively marketed to the local labour force. ${ }^{10}$ Nevertheless, a more substantive shift in spatial employment patterns will depend crucially upon the development of the skills required within the local labour force. Hence, AMEC (2013:xiv,50,83-4) argues that maximising local economic impact is dependent upon local labour market training and the establishment of apprenticeship schemes. 
In the absence of a tailored skills training programme, and even at this early stage of development, industry sources have already expressed concern over skills shortages and labour force bottlenecks. Thus, the IOD (2013:18) found that $68 \%$ of offshore contractors and $75 \%$ of operators had experienced problems in recruiting suitable employees in particular occupations within the industry. Moreover, within the oil and gas industry more generally, an Ernst \& Young survey found that a majority of respondents raised concerns that attracting suitably qualified individuals was the primary factor limiting growth in their organisation (IOD, 2013:144).

One possible response to this skilled labour supply bottleneck might involve the continued use of short term contracts and the development of a dual labour market. Hence, it may prove to be cost effective to import and adapt an existing highly skilled workforce, from Scotland and the shale gas fields currently being worked in the USA, rather than invest in the training of local residents. This cost-benefit calculation is unlikely to encompass lesser skilled occupations, as these will require less training investment and generic equivalent skills amongst the local labour force are likely to be more plentiful. Nevertheless, there would be a smaller local economic impact if a dual labour market emerged, with better paid, high skilled jobs to be imported for a 
transitory period whilst lower skill, lower paid jobs were more easily accessible by the resident labour force.

In the US shale gas industry, similar labour supply constraints were experienced (MSETC, 2011:28) and various skills training programmes were developed as a result. The most notable of these are the Petroleum Services Programme (Nicholls State University, Louisiana) and the Shale training and Education Centre (ShaleTec), formerly the Marcellus Shale Education and Training Centre (MSETC); the latter was formed out of a partnership between Pennsylvania College of Technology and Penn State Education, with some smaller initiatives investigated in the New York State (Jacquet, 2011:1-2,15-16). These initiatives provide bespoke training for the shale gas industry, and were formed at least partly to coordinate curriculum development and to overcome a high spatial distribution of workers and training providers. To facilitate this supply side development, these centres received significant public as well as industry financial investment. Indeed, ShaleTec/MSETC alone benefitted from Federal and State grants totalling £10.5m (US\$17.6m) (MSETC, 2011:52).

The need for skills training and academic research focused upon the needs of the shale gas industry has been noted by the Energy and Climate Change Select Committee (2013:38), which emphasised the importance of the establishment of partnerships 
between the shale gas industry and local educational providers, particularly universities, in reducing these labour supply constraints. However, aside from industry funded small scale initiatives, there has been nothing comparable to the US education and training centres in the UK. This may be one area where a public-private partnership may be able to facilitate the development of an emerging industry, whilst simultaneously attempting to increase the local economic impact arising out of its expansion. It might be one area where local stakeholders and their representative might engage with national government to seek pump priming investment with the dual purpose of resolving skills bottlenecks whilst simultaneously enhancing local economic gain.

One such proposal has been advanced by the Lancashire Local Economic Partnership, whereby $£ 6.2 \mathrm{~m}$ would be invested in developing Blackpool and Fylde's College facilities in order to meet some of the skills requirements of the shale gas industry. It is proposed that this initiative might dovetail with a new national government proposal, namely to develop specialist Colleges delivering the skills training needed for the sector. $^{11}$

\section{Supply Chain}

In terms of supply chain development, the economic benefits derived from agglomeration effects, through the clustering of firms involved in a given industry and 
resultant R\&D spillovers, have been extensively highlighted in the academic and business literature (Porter, 1990, 1998; Audretsch and Feldman, 1996; Cumbers et al, 2003). However, the existence of oil and gas supply chain clusters, focused upon Aberdeen which benefitted from its locational advantages for North Sea offshore exploration, may frustrate the organic development of a shale gas support network in the Lancashire area.

The offshore oil and gas industry supply chain is estimated to account for 1100 companies achieving combined revenues of $£ 27 \mathrm{bn}$ in 2011 , contributing $£ 6 \mathrm{bn}$ in corporation and payroll taxes, and supporting around 440,000 jobs across the UK (IOD, 2013:59). Approximately 45\% of the total oil and gas industry jobs in the UK are concentrated in Scotland (Oil and Gas, 2012). Thus, whilst the location of certain elements of the shale gas supply chain spatially close to the centre of the industry, preexisting specialisation in Scotland and the South East may draw additional investment outside of the Lancashire area in the absence of policy initiatives to retain significant local benefit. For example, it is anticipated that the shortage of onshore drilling rigs may be met by the Wier Group, which is based in Scotland, rather than via a new manufacturing site established in the North West (IOD, 2013:143). 
Encouragement of a clustering of onshore shale gas supply chain companies, within the Bowland-Hodder field, would not only enhance local economic impact, but would additionally contribute towards the rebalancing of the UK economy - a stated UK government objective (HM Treasury, 2014:12). ${ }^{12}$ Rather than further stimulate existing agglomeration clusters in and around Aberdeen and Greater London - both areas of the UK with above average levels of Gross Value Added (GVA) ${ }^{13}$ - the Lancashire area has below UK average GVA and would thereby narrow, rather than exacerbate, regional differentials (LCC, 2009; ASHE, 2012). Policy responses could include targeted fiscal incentives, dependent upon the spatial location of corporate activity by value. Another might be to build up local partnerships between business and universities, to create support networks and R\&D spillovers which might attract inward investment.

One recent industry-led initiative has led to the creation of the North West Energy Taskforce (NWET), supported by over 100 businesses, largely located within the region, alongside local Chambers of Commerce. ${ }^{14}$ One of its most prominent initiatives, to date, has been the organisation of a Shale Gas Supply Chain Conference (Winter Gardens, Blackpool 24th April 2014), resulting in the participation of more than 300 businesses, to discuss the potential development of supply chain links within the region. The Chair of the Blackpool, Fylde and Wyre Economic Development Company, closed the conference by warning participants that a lack of local support led to Dundee being 
overlooked in favour of Aberdeen as a base for North Sea oil offshore operations, and expressing the desire that Lancashire did not make the same mistake with an emerging onshore shale gas industry. ${ }^{15}$

\section{Fiscal Policy}

The final aspect of public policy consideration relates to fiscal policy considerations related to the shale gas industry. One element of this arose in response to local opposition to future drilling activities, the shale gas and oil industry developed a Charter whereby it commits to providing $£ 100,000$ in community benefits for each well site where fracking occurs, and $1 \%$ of revenues to local and regional communities; the latter split two-thirds to local and one-third to county levels (UKOOG, 2014). This revenue stream would be channelled through a newly established Community Foundation for Lancashire, with the stated aim to:

'work with and for local communities in a robust, effective and fully transparent independent process, supporting local people to define local communities and their priorities, including the appointment of a community panel to recommend how the money will be spent'. ${ }^{16}$

A similar scheme has operated in Lancashire, as landfill operators have contributed part of their landfill tonnage tax to not for profit bodies such as the Lancashire Environmental Fund (managed by Lancashire Wildlife Trust), and thereby funded 
projects part compensating the community and environment that have suffered through the negative externalities effects of landfill activity. These community payments, are, naturally, tax deductable (Wood, 2014).

One estimate suggests that this could provide between $£ 3$ to $£ 12 \mathrm{~m}$ of initial benefit to local communities, with a further $£ 0.3$ to $£ 0.6$ bn arising from production contributions, depending upon the size and duration of extraction (AMEC, 2013:84,122). However, the industry proposal has been labelled 'derisory' by Northern Members of Parliament, 'seriously flawed' by some of the more vigorous supporters of the shale gas industry ${ }^{17}$, and has been rejected as insufficient by the Local Government Association (House of Lords Economic Affairs Committee (2014a:36; Ev147-8).

This has led, in turn, to consideration as to whether local authorities, in affected areas, might be able to retain $100 \%$ (as opposed to the usual 50\%) of business rates, for shale gas operations (House of Lords Economic Affairs Committee, 2014a:38; 2014b:Ev166). Based upon an assumption, made by Deloitte (2013:1,10), that local authorities would receive $2 \%$ revenue in the form of business rates, this would equate to in excess of $£ 54.5$ million per annum; a total equivalent to $3 \%$ of Lancashire County Council expenditure (Deloitte, 2013:1,10). 
Nevertheless, this proposed distribution of revenues, derived from shale gas extraction activity, remains problematic for two main reasons. Firstly, despite a number of announcements and proposals, emanating from national government and industry sources, the precise magnitude and mode of distribution of the proposed community benefit remains unresolved. Indeed, there have been suggestions that any such arrangements might be open to investigation from the European Commission, pertaining to whether this qualifies as state subsidy, which is prohibited under single market legislation. ${ }^{18}$ Secondly, however, the distributional balance of benefits, between industry, national and local stakeholders, would appear to many to remain inequitable.

Pressure for an improved distribution to local communities has included a letter sent to the Prime Minister, written by local Members of Parliament from all three main political parties, alongside the leader of five affected local authorities ${ }^{19}$, arguing that local communities needed to receive more direct benefits to allay concerns over shale gas exploration. The letter argues that shale gas had the potential to produce significant economic benefits - specifically to facilitate 'a second industrial revolution and to rebalance Britain's economic output'. However, the signatories were united in their opinion that a $1 \%$ share does 'not go nearly far enough', and that, in the absence of 'significant retention' of economic benefits within the local economy, they would 'find it difficult to support further development in Lancashire'. ${ }^{20}$ Suggesting that national 
taxation may potentially absorb up to a combined $62 \%$ of revenues from the industry, Conservative MP for Preston North and Wyre Ben Wallace argued that the proposed distribution of rewards to local communities represented 'crumbs' and should be increased substantially. ${ }^{21}$ The Local Government Association (LGA) has made a counter proposal which would involve $10 \%$ of revenues from shale gas production being transferred to local communities to secure 'real strategic and additional advantage for the area'.22

The national UK budget has identified tax reforms to stimulate the development of the shale gas industry, including a new pad tax allowance of $£ 20 \mathrm{~m}$ per year (HM Treasury, 2014:35,58). Indeed, these fiscal incentives have been identified as providing the UK shale gas industry with the most competitive tax regime in Europe, and lower than equivalent rates in the US (UK Treasury, 2013:49). Set against the rather modest proposals intended to benefit local communities, and it is clear why the conflict over the distribution of shale gas benefits is likely to continue.

Furthermore, the prioritisation of tax incentives for shale gas companies has been challenged as 'questionable' by the House of Lords Economic Affairs Committee (2014a:39; Ev 169-170), given that taxation did not appear to be a significant factor, in evidence put before the committee, in preventing the expansion of the industry. This 
conclusion would seem to reinforce the other evidence presented in this paper, in that a case could be made for a shift in terms of existing fiscal support for the development of the shale gas industry, away from tax incentives and towards targeted interventions, located within affected communities, intended to enhance local skills and attract large segments of the shale gas supply chain, and thereby maximise local economic benefit.

\section{Conclusion}

The proposed expansion of shale gas extraction has been championed at national level, by government and industry sources, but the reaction in communities surrounding the shale gas fields has been markedly less enthusiastic. One reason for this may be that external costs will be likely to be borne by local residents, but the economic advantages, identified by successive reports, may provide more benefit elsewhere in the national or international economy, and thereby generate only modest local gain. Indeed, early studies tend to suggest that this scenario is likely to occur without a substantive shift in employment patterns, to create more job opportunities for local residents, and without a marked increase in the proportion of the shale gas supply chain located within the local economy. 
The paper has suggested that, although some of this effect may occur organically, the existence of established agglomeration advantages in Scotland and the South East of England, created through servicing offshore oil and gas extraction, may necessitate direct policy intervention to secure the desired level of local economic impact. This may involve the creation of a research and skills educational institution, to reduce labour supply problems for the industry and enhance the employability of the local labour force. It may also require fiscal and/or spillover incentives to attract investment into the local economy to service the shale gas industry. This may, additionally, require central government support for shale gas expansion to be redirected and focused upon these areas of greatest potential.

\section{Notes}

\footnotetext{
${ }^{1}$ Acknowledgements: The authors wish to thank Cuadrilla Resources for their sponsorship of an earlier consultancy contract and for the access of corporate data in order to facilitate the accuracy of the impact calculations contained within this paper

2 http://www.cuadrillaresources.com/benefits/jobs-and-investment/ ${ }^{3}$ http://britainthinks.com/sites/default/files/August $\% 202013 \% 20 \mathrm{Public} \% 20 \mathrm{Attitudes} \% 20$ to $\% 20 \mathrm{Natural} \% 2$ 0Gas \%20from\% 20Shale \% 20in \%20Blackpool,\%20Fy lde\%20and\%20West\%20Lancashire 0.pdf
} 
${ }^{4}$ One British Thermal Unit (BTU) is the heat required to rais e the temperature of one pound of water by one degree Fahrenheit. $1 \mathrm{mmBTU}$ equals a million BTU, and 1 trillion cubic feet (tcf) equals 1 billion mmBTU. Calculations are made at the prevalining exchange rate, $£ 1=$ US $\$ 1.68$.

5 http://www.cuadrillares ources.com/benefits/jobs-and-investment/

${ }^{6}$ http://www.bbc.co.uk/news/uk-england-lancashire-25727750

${ }^{7}$ http://www.lancashire.gov.uk/corporate/web/?siteid=6235\&pageid=36468\&e=e..$\quad$ The 12 district Lancashire area comprises: Burnley; Chorley; Fylde; Hyndburn; Lancaster; Pendle; Preston; Ribble Valley; Rossendale; South Ribble; West Lancashire; and the Wyre. A 14 authority Greater Lancashire area also includes Blackburn (with Darwen) and Blackpool.

${ }^{8}$ http://www.implan.com/

$9 \underline{\text { http://www.lancashirelep.co.uk/invest-in-lancashire/city-deal.aspx }}$

${ }^{10}$ http://www.cuadrillaresources.com/benefits/jobs-and-investment/

${ }^{11}$ https://www.gov.uk/government/uploads/system/uploads/attachment data/file/327600/19 Lancashire Growth Deal.pdf, p.7.

12 See also the Chancellor's 2014 budget speech, accessible via: https://www.gov.uk/government/speeches/chancellor-george-osbornes-budget-2014-s peech

13 Gross value added (GVA) as an indicator of wealth creation measures the contribution to the economy of each producer, industry or sector and is generally regarded as the best measure of total economic activity within an area.

${ }^{14} \underline{\mathrm{http}} / / /$ www.lancashirebusiness view.co.uk/momentum-builds-energy-task-force-37128/;

$\underline{\text { http://www.nwenergy.org.uk/ lancashire } s \text { shale is a once in a generation opportunity for our regio }}$ $\underline{\mathrm{n} \text { north west small businesses call to action on shale }}$

15 http://www.nwenergy.org.uk/supply chain conference 
16 North West Energy Task Force (2014); http://www.nwenergy.org.uk/policy; https://d3n8a8pro7vhmx.cloudfront.net/nwenergy/pages/19/attachments/original/1409446190/localbenefits-for-nw.pdf?1409446190; http://www.blackpoolgazette.co.uk/news/business/local-business/thefracking-millions-local-benefit-or-b ribe-1-6372637

17 http://www.lythamstannesexpress.co.uk/news/business/local-business/lord-s-damning-indictment-of$\underline{\text { the-government-s-push-for-fracking-1-6621131 }}$

18 http://www.telegraph.co.uk/earth/energy/10580255/Government-accused-of-overhyping-shale-gas$\underline{\text { benefits.html }}$

19 Signatories included: MP for Burnley Gordon Birtwistle (Liberal Democrat), MP for Wyre and Preston North, Ben Wallace (Conservative), MP for Blackburn Jack Straw (Labour), MP for Lancaster and Fleetwood Eric Ollerenshaw (Conservative), MP for Rossendale and Darwen Jake Berry (Conservative), MP for Bury North David Nuttall (Conservative), MP for Hyndburn Graham Jones (Labour), councillor Mike Jones, leader of Cheshire West County Council, councillor Jennifer Mein, leader of Lancashire County Council, councillor Peter Gibson, leader of Wyre Borough Council, councillor David Eaves, leader of Fylde Council and councillor Alistair Bradley, leader of Chorley District Council.

${ }^{20}$ http://www.bbc.co.uk/news/uk-england-lancashire-25727750

21 http://www.blackpoolgazette.co.uk/news/business/local-business/the-fracking-millions-local-benefitor-bribe-1-6372637; http://www.lep.co.uk/news/local/mp-s-fracking-talks-with-pm-1-6026537

22 http://www.bbc.co.uk/news/uk-england-lancashire-25727750

\section{Bibliography}


AMEC [AMEC Environment \& Infrastructure UK Limited] (2013) Strategic Environmental Assessment for Further Onshore Oil and Gas Licensing: Environmental Report. London: Department of Energy and Climate Change. Available at:

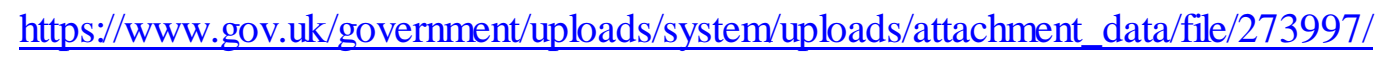
DECC_SEA_Environmental_Report.pdf

AMION (2014), Potential Economic Impacts of Shale Gas in the Ocean Gateway. Liverpool: AMION Consulting Ltd. Available at: http:/www.amion.co.uk/media/1164/potential-economic-impacts-of-shale-gas-in-theocean-gateway.pdf

Andrews IJ (2013) The Carboniferous Bowland Shale Gas Study: Geology and Resource Estimation. London: British Geological Survey for the Department of Energy and Climate Change. Available at:

https//www.gov.uk/government/uploads/system/uploads/attachment_data/file/226874/ BGS_DECC_BowlandShaleGasReport_MAIN_REPORT.pdf

ASHE [Annual Survey of Hours and Earnings] (2012) Region and Country Profiles Economy - May 2012. London: Office of National Statistics. Available at: 
http://www.ons.gov.uk/ons/guide-method/surveys/list-of-

surveys/survey.html? survey=Annual+Survey+of + Hours+and+Earnings + (ASHE)

Bolton P (2014) ‘Energy Prices', Parliamentary Briefing Paper SN/SG/4153. London:

The Stationary Office. Available at: $\underline{w w w . p a r l i a m e n t . u k / b r i e f i n g-p a p e r s / s n 04153 . p d f}$

Britain Thinks (2013), Attitudes Towards Natural Gas from Shale. London: Britain Thinks.

Civic Economics (2012) Indie Impact Study Series: A National Comparative Survey with the American Booksellers Association - Salt Lake City, Utah. Chicago: Civic Economics. Available at: http://localfirst.org/images/stories/SLC-Final-Impact-Study$\underline{\text { Series.pdf }}$

Competition Commission (2000) Supermarkets: A report on the supply of groceries from multiple stores in the United Kingdom - Vol. 2. London: Competition Commission. Available at:

http://webarchive.nationalarchives.gov.uk/+/http/www.competitioncommission.org.uk/rep_pub/reports/2000/446super.htm\#full 
DECC [Department of Energy and Climate Change] (2011) The Unconventional Hydrocarbon Resources of Britain's Onshore Basins - Shale Gas. London: The Stationary Office. Available at: https:/www.gov.uk/government/uploads/system/uploads/attachment_data/file/66172/uk -onshore-shalegas.pdf

DECC [Department of Energy and Climate Change] (2014) The Jurassic Shales of the Weald Basin: Geology and Shale Oil and Shale Gas Resource Estimation. London: The Stationary Office. Available at:

https $/ /$ www.gov.uk/government/uploads/system/uploads/attachment_data/file/313701/

BGS_DECC JurassicWealdShale_study_2014_MAIN_REPORT.pdf

Deloitte (2013), Potential Bowland Basin Shale Gas Development: Economic and Fiscal Impacts. London: Deloitte.

Domanski B and Gwosdz K (2010) Multiplier effects in local and regional development. Quaestiones Geographicae 29(2): 27-37.

Dow SG and Rodriguez-Fuetes CJ (1997), Regional Finance: A Survey. Regional Studies 31(9): 903-920. 
EY (2014) Getting Ready for UK Shale Gas: Supply Chain and Skills Requirements. London: Ernest and Young. Available at: http://www.ukoog.org.uk/images/ukoog/pdfs/Getting_ready_for_UK_shale2_gas_FINA $\underline{\text { L2022.04.14.pdf }}$

Faggian A and Biagi B (2003) Measuring regional multipliers: A comparison between two different methodologies for the case of the Italian regions. ERSA Conference Papers, ERSA03:249.

Available at: http://www-sre.wu-wien.ac.at/ersa/ersaconfs/ersa03/cdrom/papers/249.pdf

Green CA, Styles P and Baptie BJ (2012) Preese Hall Shale Gas Fracturing: Review and Recommendations for Induced Seismic Mitigation. London: Department of Energy and Climate Change. Available at:

http://og.decc.gov.uk/en/olgs/cms/explorationpro/onshore/cuadrilla_decc/cuadrilla_decc . aspx\# $w w w . d e c c . g o v . u k / . g a s / 5055$-preese-hall-shale-gas-fracturing-review

HM Treasury (2014) Budget 2014. London: The Stationary Office. Available at: https $/ /$ www.gov.uk/government/uploads/system/uploads/attachment_data/file/293759/3 7630_Budget_2014_Web_Accessible.pdf 
House of Commons Energy and Climate Change Committee (2013) The Impact of Shale Gas on Energy Markets - HC 785. London: The Stationary Office. Available at: http://www.publications.parliament.uk/pa/cm201213/cmselect/cmenergy/785/785.pdf

House of Lords Economic Affairs Committee (2014) The Economic Impact on UK Energy Policy of Shale Gas and Oil - HL 172. London: The Stationary Office. Available at: http://www.publications.parliament.uk/pa/ld201314/ldselect/ldeconaf/172/172.pdf House of Lords Economic Affairs Committee (2014) The Economic Impact on UK Energy Policy of Shale Gas and Oil: Appendix - Oral and Written Evidence HL 172. London: The Stationary Office. Available at: http://www.parliament.uk/documents/lordscommittees/economic-affairs/EnergyPolicy/EAC-energy-ev-vol.pdf

IOD [Institute of Directors] (2013) Getting Shale Gas Working. London: IOD. Available at: http://www.iod.com/influencing/policy-papers/infrastructure/infrastructure-forbusiness-getting-shale-gas-working 
La Trobe H (2002) Local food, future directions. London: Friends of the Earth.

LCC [Lancashire County Council] (2009) Local Gross Value Added, 1997-2009. Available at:

http://www.lancashire.gov.uk/corporate/web/?siteid=6235\&pageid=36468\&e=e .

McCann P (2013) Modern Urban and Regional Economics. Oxford: Oxford University Press, second edition.

McCombie JSL and Thirwall AP (1994) Economic Growth and the Balance of Payments Constraint. London: Pagrave.

MSETC (2011) Pennsylvania Marcellus Shale Workforce Needs Assessment.

Pennsylvania: Marcellus Shale Education and Training Centre. Available at:

http://www.shaletec.org/docs/PennsylvaniaStatewideWorkforceAssessmentv1_Final.pd

$\underline{\mathrm{f} \text { Zzoom }=75}$

North West Energy Task Force (2014), What Local Benefits Will Shale Gas Extraction Bring to the North West?. Available at: http://www.nwenergy.org.uk/policy; 
https://d3n8a8pro7vhmx.cloudfront.net/nwenergy/pages/19/attachments/original/1409446190/localbenefits-for-nw.pdf? 1409446190

Patel A and Martin G (2011) Going Local: Quantifying the Economic Impacts of Buying from Locally Owned Businesses in Portland, Maine. Augusta: Main Centre for Economic Policy (MECEP). Available at: www.mecep.org/av.asp?na=383

Rodgers H (2013) UK Shale Gas - Hype, Reality and Difficult Questions. Oxford: Oxford Institute for Energy Studies. Available at: http://www.oxfordenergy.org/wpcms/wp-content/uploads/2013/07/UK-Shale-Gas$\underline{\text { GPC1.pdf }}$

Sachs J (2002) The Money Trail: Measuring Your Impact on the Local Economy using LM3 [Local Multiplier 3]. London: New Economics Foundation. Available at: http://www.pluggingtheleaks.org/downloads/the_money_trail.pdf

UK Treasury (2013) Autumn Statement 2013 - Cm. 8747. London: The Stationary Office. Available at:

https:/www.gov.uk/government/uploads/system/uploads/attachment_data/file/263942/3 5062_Autumn_Statement_2013.pdf 
UKOOG [United Kingdom Onshore Operators Group] (2014) Community Engagement Charter: Oil and gas from Unconventional Reservoirs. Available at:

http://www.ukoog.org.uk/images/ukoog/pdfs/communityengagementcharterversion6.pd

$\underline{f}$

US Energy Information Administration (2011) World Shale Gas Resources: An Assessment of 14 Regions Outside the United States. Washington DC: US Department of Energy. Available at: http:/www.eia.gov/analysis/studies/worldshalegas/

Ward B and Lewis J (2002) Plugging the Leaks: Making the Most of Every Pound that Enters Your Local Economy. London: New Economics Foundation. Available at: http://www.neweconomics.org/publications/entry/plugging-the-leaks

White, E., Fell, M., Smith, L. And Keep, M. (2014), 'Shale Gas and Fracking', Paliamentary Briefing 201, SN/SC/6073. London: The Stationary Office.

Wood R, Gilbert P, Sharmina M and Anderson K (2011) Shale Gas: A Provisional Assessment of Climate Change and Environmental Impacts. Manchester: The Tyndale Centre. Available at: http://www.tyndall.ac.uk/sites/default/files/coop_shale_gas_report_final_200111.pdf 
Wood I (2014) UK Continental Shelf Maximising Recovery Review: Final Report.

London: The Stationary Office. Available at:

http://www.woodreview.co.uk/documents/UKCS\%20Maximising\%20Recovery\%20Re

view\%20FINAL\%2072pp\%20locked.pdf 